\title{
FILM THEORY
}

Gary Bettinson

\begin{abstract}
In this chapter I review six contributions to the field of film theory published in 2018: Carl Plantinga's Screen Stories: Emotion and the Ethics of Engagement (Oxford University Press); Miklós Kiss and Steven Willemsen's Impossible Puzzle Films: A Cognitive Approach to Contemporary Complex Cinema (Edinburgh University Press); Nicholas Godfrey's The Limits of Auteurism: Case Studies in the Critically Constructed New Hollywood (Rutgers University Press); Peter Krämer and Yannis Tzioumakis’ The Hollywood Renaissance: Revisiting American Cinema's Most Celebrated Era (Bloomsbury Academic); Dorothy Wai Sim Lau's Chinese Stardom in Participatory Cyberculture (Edinburgh University Press); and Gina Marchetti's Citing China: Politics, Postmodernism, and World Cinema (University of Hawaii Press). The chapter consists of three sections: 1. Cognition, Emotion, and Ethics; 2. The New Hollywood; 3. Contemporary Chinese Cinema.
\end{abstract}

\section{Cognition, Emotion, and Ethics}

Carl Plantinga's monograph investigates the ethics of 'screen stories,' a category encompassing all moving-image media 'produced for and viewed on any type of screen' ( $p$. 1). Focusing centrally on long-form fictional narratives in film and television, Plantinga asks: 'What sort of ethical experience and thinking do screen stories encourage? And how do the screen stories we view influence ethical sensitivity, judgment, focus, action, and belief?' (p. 1). A key area of exploration for Plantinga is emotion, since emotion and affect figure strongly in the persuasive power of stories. Plantinga knows this territory well: his previous monograph, Moving Viewers: American Film and the Spectator's Experience (University of California Press, 2009), illuminated the process of 'affect elicitation' in Hollywood movies. Screen Stories is both a logical outgrowth and a significant expansion of that earlier work. 
Before tracing the book's core argument, it is worth sketching its broad perspective. In the tradition of cognitive film theory, Screen Stories seeks to redress some influential fallacies promulgated by so-called Grand Theory (i.e. large-scale theories of cinema that purport to explain broad psychic and cultural mechanisms). One particular set of spurious concepts Plantinga terms 'estrangement theory.' Proponents of estrangement theory hold that mainstream cinema, by means of an immersive and seductive discourse, yields hypnotic effect: the deterministic film text curtails the spectator's critical faculties, imparts noxious (capitalist) ideology, and induces ethical inertia. Reflexive and recondite films, by contrast, emancipate the viewer from psychic slumber and ideological coercion. Correspondingly, estrangement theorists prize art films such as Tout va bien (1972), whose deployment of 'alienation effects' purportedly liberates the viewer's agency. Plantinga is justifiably sceptical of these premises, proposing 'engagement theory' as 'a more useful way of considering ethical issues' (p. 6). The ethical dimension of screen stories, he contends, is often encountered by engagement with - rather than estrangement from - the film's narrative, characters, and various cognitive and affective appeals. Narrative immersion, as Plantinga puts it, 'may in fact encourage critical thinking' (p. 108).

If estrangement theorists attend chiefly to modernist and avant-garde texts, Plantinga admits less exalted artworks into his sphere of analysis. By devoting space to The Twilight Zone (1959-1964) and The Hunger Games (2012), for example, he undertakes to address the dominant sorts of screen entertainment that shape individuals and culture, as well as to rescue mainstream storytelling from the deep-rooted fallacies of estrangement theory. Plantinga further distinguishes his approach from Grand Theory by insisting that 'the impact of screen stories must be determined on a case-by-case basis' (p. 95). Rather than postulating an $a$ priori, totalizing thesis - that, say, popular cinema stultifies the active consciousness of the spectator - Plantinga's ethics of engagement aligns with the 'bottom-up' and 'piecemeal' theorizing espoused by David Bordwell, Noël Carroll, and other cognitive media theorists.

Plantinga construes screen stories as rhetorical constructs, the power of which lies in their strategies of engagement with narratives, agents, and situations. Screen stories, then, tend to be inherently didactic; they advocate, more or less overtly, certain favoured attitudes and positions. A film like Philadelphia (1993) 'makes a case': by means of emotive rhetoric (or 
what Plantinga calls enticements, incentives, or psychological bribes), the film solicits sympathy for its protagonist, Andrew Beckett (Tom Hanks), a homosexual dying of AIDS. Philadelphia mobilizes an arsenal of rhetorical tactics to win the spectator to its perspective. Its deployment of narrative structure, emotionally-loaded scenarios, affective tone or mood, and other strategies of persuasion, combines to foster a strong sympathetic allegiance with Beckett. For the spectator, the chief payoff (or 'reward') for cooperating with Philadelphia's rhetorical project is affective pleasure. In all of these ways - presenting a case, coaxing the viewer to assent to that case, and providing compensation in the form of affective gratification - Philadelphia typifies the way that many screen stories operate (at least, according to Plantinga).

But there is more. Mass narratives, such as Philadelphia, wield the capacity to 'alter our mental schemas' (p. 73) and thereby 'initiate social change' (p. 147). The attitudes and responses elicited by the screen story may, through a process of 'transference,' recalibrate the spectator's real-world dispositions. Such is the emotional richness of Beckett's pitiable path in Philadelphia - a spatiotemporal path with which the compliant spectator is closely aligned - that even a homophobic viewer may come to view Beckett with compassion, and apply that newfound sympathy to gay people and AIDS sufferers in the actual world. For all these reasons - their innate didacticism, rhetorical potency, and capacity to affect real-world attitudes - screen stories demand close ethical scrutiny.

Plantinga exemplifies his ethics of engagement with admirable clarity, advancing his theory across three major sections. In Part I ('The Power of Screen Stories') and Part II ('Ethics and Engagement'), he demonstrates that immersive narratives, character engagement, and emotional absorption - disparaged as unethical by estrangement theorists - are often crucial to the spectator's ethical engagement with screen stories. In Part III ('The Contours of Engagement'), he homes in on three textual features that harbour ethical influence: character engagement, narrative structure, and paradigm scenarios. The reader will notice that the issue of character engagement traverses the book. Screen stories usually elicit 'pro' attitudes toward their protagonists, and Plantinga recognizes the rhetorical force of character engagement as a storytelling device: 'By enlisting allegiance for a protagonist, a film can make attractive the sort of virtues and ethical choices the character represents' (p. 44). In 
some cases, the character with whom the viewer develops an allegiance elicits projectionthat is, the viewer's 'wish to emulate [the character]' (p. 204), and to adopt, in the actual world, the character's 'actions or perspectives' (p. 92).

Plantinga's claims here, and the rhetorical efficacy he ascribes to character engagement, seem to me largely convincing. But I think he scants the role of the screen star in spectator responses of allegiance and projection. Spectators form allegiances not simply with characters - that is, textual analogues of human agents - but with the embodied portrayal of characters by screen actors and stars. If, as Plantinga claims (p. 199), we sympathize with Harry Osborne (James Franco) in Spider-Man (2002), to what degree, if at all, is James Franco influential upon our sympathetic attachment to Harry? Passingly, Plantinga notes that screen characters are often played by 'familiar and well-liked stars' (p. 204) - but not all stars are universally liked. How might a spectator's personal distaste for James Franco fare against the narration's powerful, rhetorical efforts to foster allegiance with Harry? Moreover, the offscreen lives of actors - their affiliated causes, projects, and politics - can bear importantly on the rhetorical credence of the story in which they participate. From John Wayne in Big Jim McLain (1952) to Jane Fonda in Coming Home (1978), a screen story's capacity to persuade - i.e. to 'make a case' - can be boosted (or undermined) by star casting.

Most contentious is the book's final section. Here Plantinga discloses 'some of [his own] personal ethical perspectives' (p. 114). He finds, for instance, the construction of masculinity displayed in Legends of the Fall (1994) to be ethically troubling. Edward Zwick's lachrymose Western elicits allegiance with a protagonist, Tristan (Brad Pitt), whose idealized 'masculine' behaviour is presented as barbaric and vengeful yet 'natural' and heroic, even beautiful (pp. 207-9). Tristan's ferocity springs largely from his thirst for revenge, and Plantinga reserves his chief criticism for screen stories that exploit revenge tropes (or 'paradigm scenarios') in unethical ways. Django Unchained (2012) provides an instance. Quentin Tarantino's enslaved protagonist, Django (Jamie Foxx), initially seeks suffrage; once emancipated, he pursues retribution against those who hold his wife in bondage. For Plantinga, Django Unchained 'works to cultivate vengefulness,' its historical milieu of black slavery but a pretext 'to accelerate the audience's pleasure in revenge' (p. 238). Here, then, is the pernicious side of transference: by generating 'a desire for violent outcomes' (p. 232), the 
revenge scenario 'may cultivate the view that, in the face of offense or insult, vengeful action...saves the day' (p. 239).

It bears noting that Plantinga's criticism of the revenge scenario is not prescriptive: he does not propose a ban on such narratives, and he grants that some readers may quarrel with his ethical judgments. Rather, he maintains, the spectator should approach all screen stories with 'ethical vigilance' (p. 107). Apropos the revenge scenario, Plantinga champions films that throw doubt on the propriety of revenge and the pleasurable emotions that attend it. He offers as instances Westerns such as Winchester '73 (1950) and True Grit (2010). One suspects that Plantinga would also approve of The Crossing Guard (1995), an urban drama in which a bereaved father (Jack Nicholson) seeks revenge against the hit-and-run driver responsible for his daughter's death. Initially the film arouses the viewer's desire to see vengeance enacted, only to radically subvert this desire; by the film's end, the revenge narrative has fizzled, and the father finds catharsis in redemption rather than revenge.

Why is this section of Screen Stories contentious? If Philadelphia can convert a homophobe, can't Django Unchained spur a spectator to violence? If screen stories 'create culture' (p. 75), doesn't the revenge scenario endanger socio-moral norms? I'm not sure that the revenge scenario warrants such circumspection. Philadelphia's 'case' may be effective because, beyond its intrinsic rhetorical dexterity, the film's progressive ideology has coincided with a diffuse, gradual societal shift (in Western cultures, at least) toward an acceptance of homosexuality. Mass shifts of this sort can effect attitudinal change ('recalibration') in individuals and groups. No such societal shift promotes violent revenge as a desirable development. Though screen stories wield persuasive power - Plantinga's book is wholly convincing on this point - the socially-regulated environment still provides viewers with moral ballast, such that audiences may enjoy revenge fantasies without being compelled to mete out revenge in the actual world.

Screen Stories is afflicted by some peculiar flaws - a mooted analysis of 300 (2006) doesn't materialize, for instance; and repetitiousness retards certain chapters - but such quibbles fade in light of the book's real achievements. Plantinga expertly demonstrates the rhetorical and 
affective force of moving-image media; he lays bare the tactics by which screen media present a 'case'; and if he warns of the ethical risks inherent in certain screen stories, he also foregrounds - refreshingly and cogently - the ethical goods of which screen stories are capable.

Plantinga reminds us that the cognitive paradigm, though hobgoblinized by certain factions within the discipline, tangibly enriches the domain of film theory. The profit of cognitivism also shines through in Miklós Kiss and Steven Willemsen's Impossible Puzzle Films. The authors focus on a 'palpable trend of narrative complexity in contemporary cinema' (p. 3) - a trend initiated, it seems, by Tarantino's Pulp Fiction in 1994, and probed further by such formally and cognitively 'complexifying' films as Memento (2000), Mulholland Drive (2001), Donnie Darko (2001), The Prestige (2006), and Inherent Vice (2014), among others. This recent trend is not so much sui generis as a 'resurgence' and an expansion - indeed, a 'mainstreamification' (p. 10) - of storytelling modes flirted with during Hollywood's classical era and de rigeur in European art cinema since at least the 1950s (p. 12). Kiss and Willemsen launch several lines of inquiry: What has propelled this resurgence in filmic complexity? How do puzzle films conjure their complex effects? By what strategies do spectators attempt to subdue cognitive puzzlement? Why do viewers find indecipherable plots pleasurable?

The authors find existing definitions of 'puzzle films' to be both imprecise and diffuse, not to say historically rigid. At its broadest compass, the puzzle-film category denotes films that deliver complex viewing experiences, often by ambiguating the viewer's ontological and epistemic knowledge. Unreliable narration, causal ambiguity, scrambled chronology, character multiplications, impossible milieus, bewildering metalepses - these are the kinds of stratagems by which puzzle films disorient viewers. Perhaps surprisingly, Kiss and Willemsen reconceptualize puzzle films in such a way that excludes certain films thought to epitomize the genre, such as The Sixth Sense (1999), Fight Club (1999), and The Usual Suspects (1995). These 'unreliable twist movies,' while generating momentary disorientation and surprise, subject viewers to neither sustained ambiguity nor genuine puzzlement. Such films therefore 'do not really complexify the viewing experience' (p. 53). Instead, the authors identify a mode of complex storytelling that is genuinely complex: the 'impossible puzzle 
film,' as they term it, typified by narratively irresolvable movies including Lost Highway (1997), Inland Empire (2006), Enemy (2013), and Primer (2004). In addition, the authors though they restrict their purview to contemporary cases - propose to 'detach the term "puzzle film” from its historical specificity' (pp. 51-52), the better to magnify the current trend's debt to foregoing traditions.

To be distinguished from 'impossible' puzzle films are 'disorienting but solvable' puzzle films, the composition of which delivers prolonged complexity before an elucidating climax resolves the central plot imbroglio. Examples include Run Lola Run (1998), Cloud Atlas (2012), and Inception (2010). Impossible puzzle films, by contrast, furnish insoluble narratives. By means of plot 'incongruities' (contradictory narrative elements) and 'impossibilities' (violations of the viewer's mental schemas), these films suspend the viewer in a perpetual state of cognitive dissonance. Thus denied the viewer (we might add) is what cognitivists call 'insight' - an 'aha' or 'eureka' moment that attends one's sudden solution to a complex problem.

Why would viewers find such knotty, equivocal storytelling gratifying? What kinds of viewing activity do impossible puzzle films evoke? Kiss and Willemsen offer some provocative hypotheses. Whereas 'traditional' films produce viewer passivity, impossible puzzle films engender 'empowered modes of viewership' (p. 16; p. 25). Classical narratives involve the viewer in deductive and top-down activity, but impossible puzzle films demand greater cognitive effort, the narrative's thwarting of mental schemas a stimulus for the viewer's inductive, top-down cognition (p. 88). So labyrinthine are the puzzle plots' enigmas that viewers engage 'forensically' with the film (p. 16). They embark on a quest for narrative disambiguation; apply sense-making schemas to baffling elements; and employ 'dissonancereduction strategies' as a bulwark against psychological confusion (p. 106). Here is one source of the impossible puzzle film's attraction: viewers find rewarding the effort to subdue cognitive dissonance, test hypotheses against recalcitrant data, and ascribe meanings to abstruse story elements. Thus it is not dissonance itself but the attempt to overcome dissonance that viewers find fulfilling. 
Impossible puzzle films, meanwhile, foster the viewer's sense-making efforts, continually proffering 'hermeneutic bait' as a means to sustain attention, immersion, and the desire for narrative elucidation (p. 63). Not least, such films exploit classical Hollywood schemas of narrative comprehension and closure. By strategically animating 'classical narrativising and rational sense-making strategies' (p. 163), impossible puzzle films gull the viewer into assuming that the esoteric plot is logically decipherable and resolvable. Ultimately, however, these films refuse cognitive resolution. Yet even the denial of a hermeneutic payoff can invigorate the forensic, empowered viewer, whose thirst for cognitive 'insight' - sometimes triggered by official paratextual material, as in the case of Donnie Darko - may extend far beyond the film viewing experience, and indefinitely into the future. As Kiss and Willemsen plausibly conclude, 'feeling "challenged" by complex movies may be more important than solving their puzzles' (p. 207).

Persuasive as these arguments are, Kiss and Willemsen - in their haste to assert the purposeful agency of puzzle-film viewers - downplay the cognitive effort involved in 'traditional' film viewing. The 'traditional passive role of viewers-as-spectators' is one whereby 'audiences...submit themselves' to the screening situation (p. 13); and central to this mode of spectatorship, as Laura Mulvey has taught us, are spectatorial processes of voyeurism and identification (p. 16). This sketch of the film viewer cannot but call to mind the 'subject-position' theory that reigned over the discipline in the 1970s - an evocation reinforced by the authors' approving nod to Mulvey. Imputing passivity to the film viewer, however, strikes me as ipso facto anathema to a cognitive account of spectatorship. Indeed, cognitivists have robustly contested Grand Theories of spectator passivity and voyeurism, while also rescuing 'identification' from psychoanalytic obfuscation (Plantinga is an instrumental figure here).

It is regrettable, too, that Kiss and Willemsen cleave their analysis wholly to principles of 'story-related complexity' (p. 3), however skilful may be their explication of these principles. From the outset, the authors rivet their analysis to narrative design, addressing 'film style or sound [only] to the degree that these take on explicit relevance in relation to issues of narrative' (p. 4). Yet, to shirk stylistic analysis is to account only partially for how impossible puzzle films function as complex objects. Consider three brief instances. Triangle (2009) 
presents multiple variants of its chief protagonist, Jess (Melissa George), whose respective paths diverge yet intersect thanks to a nefarious, inexplicable temporal loop. Kiss and Willemsen deftly illuminate the plot's architectural design; and, to be fair, they provide acute (albeit fleeting) stylistic analysis of a particularly slippery scene (p. 173). Neglected, however, is a host of visual and sonic devices by which Triangle vexes the viewer's experience and/or hints at an impossible diegesis: shot repetitions that ambiguate temporal specificity; jump cuts yielding spatiotemporal disjunctures; multi-panel mirrors that duplicate bodies ad infinitum; equivocating shots that either signal a logical ellipsis or reveal a parallel reality; a prowling camera apt to desert the characters and forge an intentional path of its own; intertextual visual allusions that recall other temporally impossible narratives (e.g. The Shining [1980]); a subjective and unreliable voiceover track; and so on.

The authors indicate that Triangle 'uses very traditional point-of-view editing' (p. 173), but at least one scene monkeys with the POV device. Stranded at sea, Jess and her companions board an abandoned ocean liner. Jess trails closely behind the group as they search the ship's passageways. Jess looks behind her; a cut to an empty corridor implies Jess's POV, but then Jess's companions wander into frame. Our POV inference, it seems, was erroneous, since we see Jess's comrades from a vantage point that Jess does not occupy. Yet, in light of the plot's subsequent revelation - that the ship plays host to multiple versions of Jess - perhaps the shot that we identified and dismissed as Jess's POV does indeed represent Jess's optical POV after all, only one that belongs to another incarnation of Jess, skulking off screen.

A second instance is Primer, an impossible puzzle film whose time-travel plot (the authors note) seeks cogency through quasi-scientific dialogue (p. 180). As several critics have carped, however, much of Primer's dialogue is not only impenetrable but also inaudible - an acoustic trait not broached by Kiss and Willemsen. The film's grainy $16 \mathrm{~mm}$ film stock, which confers upon the action a texture untypical of most mainstream movies, also goes unremarked by the authors. How do such stylistic idiosyncrasies compound or clarify the narrative puzzle? How do they facilitate the viewer's imputed 'immersion' in the fiction? 
Finally, the authors claim that Chungking Express (1994) "links" its disjointed plots through mere spatial contiguity' (p. 40). Yet if one attends not solely to the film's macrostructure but also to its various visual and aural motifs (clocks, mirrors, aeroplanes, expiry dates, music cues, character 'cameos' that bridge the twin blocks of action, and so on), one finds that the successive, causally-ambiguous plotlines are yoked more thoroughly than the authors suggest. In sum, confining analysis chiefly to the level of narrative construction does not, I submit, do full justice to the ways puzzle films 'complexify the viewing experience' (p. 53).

Nevertheless, one can lament these (self-imposed) constraints and still recognize and applaud the book's ambitiousness. Impossible Puzzle Films is a dense, probing, truly enlightening study of a salient trend within world cinema. Like Plantinga, Kiss and Willemsen offer an enriching perspective on cinema's cognitive and affective power, its capacity to beguile, bewilder, and delight.

\section{The New Hollywood}

Most film scholars agree that a new breed of Hollywood filmmaking - self-consciously auteurist, inflected with European art-film techniques, honeycombed with ennui, and iconoclastic or ludic in its approach to genre - emerged in the late-1960s. Inaugurated by Bonnie and Clyde and The Graduate in 1967, the short-lived 'New Hollywood' era yielded a corpus of critically-lauded films including The Godfather (1972), Chinatown (1974), and Dog Day Afternoon (1975). Here, however, critical consensus begins to disintegrate. As Nicholas Godfrey points out in The Limits of Auteurism, the critically constructed New Hollywood exhibits 'canonical instability' (p. 10). For one thing, the canon is historically imprecise. When, for instance, did the New Hollywood end? Godfrey traces its demise to Star Wars in 1977, but critics variously posit 1975 (Jaws), 1979 (Apocalypse Now), or 1981 (Raiders of the Lost Ark) as termination points. Nor is there unanimity as to which films belong in the canon. Is Dirty Harry (1971) - in many respects a traditional policier - properly subsumed to the experimental New Hollywood? Why does the canon exclude many 1970s movies centred on women and racial minorities? Then there is the fungible phrase itself ('New Hollywood'), which has at times been conflated with 'American Renaissance' and 'Hollywood Renaissance' (p. 10). (Godfrey might have added 'American New Wave' and 
'New New Hollywood,' equally vague ascriptions that bedevil the process of categorization.) Seeking to redress the canon's conceptual fuzziness, Godfrey pursues 'a more meaningful, concrete historical model' of the New Hollywood era (p. 10).

A concise introduction sets forth an ambitious array of tasks. The Limits of Auteurism aims to: 'identify the characteristics that distinguish New Hollywood films' from their classical forbears (p. 2); probe the extent to which industrial practices shape aesthetic outcomes; calibrate the critics' role in canon formation; chart canonical change; disclose the canon's ties to stardom and distribution; reveal the political bias of particular films; and explore New Hollywood depictions of gender, race, ethnicity, and sexuality. Isolating Easy Rider (1969) as a seminal prototype, Godfrey traces the film's impact on two New Hollywood 'cycles': the 'youth-cult film' (often thematising existential anomie) and the 'violent cop' movie (centred on renegade police detectives). Both cycles, Godfrey demonstrates, emulate or 'repackage' Easy Rider's innovations at the level of aesthetic design (e.g. documentary stylistics; fatalistic narratives), mode of production (e.g. independent financing), and distribution strategy (e.g. acquisition by major studios). Godfrey derives his main case studies from both cycles, organizing each chapter around an exemplary film. Most chapters recount their film's production history; analyse characterization and star embodiment; examine form and style; and delineate critical reaction.

The Limits of Auteurism theorizes the New Hollywood afresh, furnishing an incisive revisionist account of a hallowed era in American filmmaking. For all its virtues, however, the book errs in its retrospective appraisal of sexual politics. Consider Godfrey's otherwise excellent analysis of Five Easy Pieces (1970). The film, which Godfrey takes as a prime instance of the youth-cult film, centres on Bobby Dupea (Jack Nicholson), a disaffected, not to say apathetic, drifter isolated between social classes, rival domiciles, and female intimates. Among the latter are Bobby's needy girlfriend, Rayette (Karen Black), sister Partita (Lois Smith), and lover Catherine (Susan Anspach), fiancée of Bobby's aloof brother Carl (Ralph Waite). Other women glide in and out of the action: a haughty waitress, an overbearing intellectual, and a pair of lesbian hitchhikers, each of whom becomes a target for Bobby's corrosive wit. 
Bobby treats some of these women callously, to be sure, but Godfrey is too eager to convict Five Easy Pieces of sexism and misogyny. He decries, for instance, the 'misogynistic' portrayal of the hitchhikers 'as caricatures to be mocked' (p. 54). Yet even if one grants this claim, one must acknowledge that two comparatively major characters - Catherine and Partita - are portrayed as multifaceted, self-sufficient, sharply intelligent women worthy of the viewer's admiration. Nor is caricature, if it be so, exclusively reserved for female characters: Carl - frumpish, staid, and encumbered by an ungainly neck brace - is no less an object of ridicule than the nutty hitchhikers.

For Godfrey, the 'sexism' of Five Easy Pieces finds a precedent in Easy Rider. If the latter film consigned female characters to predominantly submissive and sexualized roles, then 'Five Easy Pieces is similarly cruel in its portrayal of Rayette, who is at best regarded as a nuisance to Bobby' (p. 54). This remark, however, betrays a basic misattribution: Bobby treats Rayette cruelly, certainly, but the film presents Rayette in fundamentally sympathetic terms. Throughout his analysis, Godfrey routinely mistakes Bobby's sexist behaviour for the film's sexual politics. Yet Five Easy Pieces enjoins us neither to share Bobby's attitudes nor to endorse his behaviour, but rather to adopt a critical stance toward him. A similar misreading befalls some brief remarks on Carnal Knowledge (1971). 'In retrospect,' Godfrey writes, '[Carnal Knowledge's] leering, sneering nastiness is readily apparent' (p. 200). These words ('leering, sneering nastiness') quite neatly evoke the central character, Jonathan (Jack Nicholson, again); but they hardly describe the film's attitude toward either its chauvinistic protagonist or the female characters drawn into his orbit. Carnal Knowledge is unequivocal on this issue: Jonathan is no kind of male ego-ideal. By the film's end, he is literally impotent, spiritually desolate, and utterly bereft of meaningful intimacy.

Neither Five Easy Pieces nor Carnal Knowledge, then, should be charged with misogyny. Nor, for that matter, is Bobby Dupea adequately characterized by misogynist traits: for one thing, he displays genuine respect and affection for Partita; for another, his animus is not solely aimed at women (he is similarly odious toward co-worker Elton and Carl). Bobby's hostility, in other words, is existential and promiscuous - it does not discriminate between the 
sexes. If Godfrey neglects these points, he also shrinks from the implications of New Hollywood's purported sexism, misogyny, and homophobia. Here is one cluster of questions left begging: To whom does Godfrey attribute the misogynist streak in Five Easy Pieces? (Presumably not to Carole Eastman, the female author of the film's screenplay.) Is the critically-forged New Hollywood canon 'sexist'? (Godfrey implies that it is.) If yes, then is it intentionally or unconsciously so? To what extent (if at all) does the prism of twenty-first century identity politics distort the prejudice or progressiveness of particular New Hollywood films? The Limits of Auteurism leaves such questions dangling. More generally, while Godfrey's critique of sexual politics unfairly castigates certain films (such as Five Easy Pieces), it overpraises others (such as The Boys in the Band [1970], improbably commended here for its 'clear-eyed, even-handed' depiction of homosexuality [p. 150]).

One last demurral: The Limits of Auteurism contains fairly extensive but uncritically recycled testimony from Dennis Hopper. On the one hand, privileging Hopper's voice is reasonable enough, given the historical significance that Godfrey ascribes to Easy Rider. On the other hand, one might aver that Hopper - a notoriously drug-addled, self-aggrandizing figure in the 1960s and 1970s - might just be an unreliable interpreter and chronicler of Easy Rider and its production history. Indeed, Hopper's authorship of Easy Rider has long been in dispute. My main point, though, is this: If the New Hollywood canon has been retrospectively constructed by film critics, so the era's filmmakers have participated in the process of canonization by virtue of their interviews, speeches, and other public declarations. (Often, of course, these declarations arise from interaction with critics.) Godfrey might have approached Hopper's testimony with greater scepticism, yes, but also with a view to show how star/auteur discourse helped to shape the New Hollywood canon.

Lest my remarks seem too critical, I should reiterate that The Limits of Auteurism represents a significant, truly illuminating contribution to the field. In attractive prose, Godfrey justly contests the somewhat arbitrary, exclusionary contours of the New Hollywood canon; gives overdue attention to key women filmmakers (such as Carole Eastman); highlights the canon's omission or marginalization of female directors, films about women, and the Blaxploitation and kung-fu cycles; and offers penetrating analyses of particular films. Time and again, Godfrey's revisionist angle bears fruit. Whether foregrounding Easy Rider's moral 
conservatism (p. 26) or disclosing the sympathetic portrait of women in Dirty Harry (p. 159), Godfrey subjects familiar films to fresh scrutiny. He also sheds light on relative obscurities (Little Fauss and Big Halsy [1970]; Adam at 6 A.M. [1970]). Among other insights, Godfrey pinpoints the year 1971 as a watershed in the New Hollywood's development, auguring the era's precipitous decline. By 1971, Godfrey reveals, the audience had grown restless with New Hollywood experimentation. Critics, too, began expressing fatigue toward the industry's auteurist ventures. The critical and commercial failure of Hopper's aptly-titled The Last Movie (1971), among other films, hints at the 'limits of auteurism' inscribed in the book's title.

Those limits also provide the mainspring for The Hollywood Renaissance, edited by Peter Krämer and Yannis Tzioumakis. This anthology departs from Godfrey in several respects: the editors reject the phrase 'New Hollywood' in favour of 'Hollywood Renaissance' as shorthand for the era of 'innovative' American cinema inaugurated in the late 1960s; they circumscribe this era more narrowly than does Godfrey, treating 1974 (rather than 1977) as its probable terminus; and while Godfrey seeks to distinguish old cinema from new, Krämer and Tzioumakis more circumspectly stress historical continuity as well as change (p. xv). Beyond these points of difference, however, the two books share notable affinities. Both volumes question the axioms found in standard accounts of the period; both find fault with the canon insofar as it privileges white male directors, protagonists, and audiences; and both, more or less emphatically, rebuke the auteur theory for slighting creative personnel other than the director. Nevertheless, Godfrey's enterprise largely keeps auteurism at centre stage. The Hollywood Renaissance, by contrast, underscores artistic collaboration and multiple authorship, foregrounding the pivotal roles played by editors (e.g. Dede Allen), producers (e.g. Joseph E. Levine), cinematographers (e.g. Haskell Wexler), and actors (e.g. Barbra Streisand).

How to upgrade the era's neglected contributors? One stratagem, adopted by several writers in this collection, repositions the undervalued participant as uncredited director. Peter Krämer flirts with this tactic, as a kind of parting sally, in his useful account of Barbra Streisand's early stardom. Streisand, a major film star since the late 1960s, is nobody's idea of an unappreciated talent. But neither Streisand herself, nor the initial films in which she acted 
(from Funny Girl [1968] to The Way We Were [1973]), feature prominently in standard accounts of the Hollywood Renaissance. Krämer examines Streisand's unconventional stardom - her 'upfront Jewishness' (p. 65), aquiline nose, and relative youth - before going on to note the star's proclivity to battle her directors for creative control. Though Streisand did not direct a film (at least, not officially) until the Renaissance was over, Krämer floats the question: 'Could we say...that Barbra Streisand was, in fact, a Hollywood Renaissance filmmaker...?' (p. 66). This proposition at once promotes Streisand (before her time, we might say) to auteur status and relegates the director of record (William Wyler, Vincente Minnelli, Sydney Pollack, et al.) to the rank of hired hand.

R. Colin Tait executes a similar but not quite equivalent move in an intriguing chapter on Robert De Niro, Martin Scorsese, and Mean Streets (1973). De Niro, Tait contends, has been largely omitted from 'auteur-driven histories of the Hollywood Renaissance' (p. 204). No 'mere' actor, De Niro tenders varieties of 'uncredited labour': he improvises scenes, partakes in wardrobe decisions, and assists in the casting process, thereby demonstrably shaping the finished work. Tait posits De Niro not as de facto author but as one half of a 'creative pair' (p. 204): 'The De Niro-Scorsese films, especially the ones they made during the 1970s, are not the product of a single auteurist sensibility, but are "co-owned" by [Scorsese and De Niro]' (p. 206). Like Streisand, then, De Niro merits authorial recognition (without, by Tait's reckoning, the need to dethrone Scorsese).

By faulting auteurism on empirical grounds, and by exalting unsung contributors, Krämer's and Tait's chapters echo recent scholarship on Renaissance filmmakers. For instance, James Mairata's Steven Spielberg's Style By Stealth (Palgrave Macmillan, 2018) disparages authorial studies of Spielberg's oeuvre, citing vital contributions by Spielberg's collaborators as proof of multiple authorship. (Mairata's book ultimately fails to evade auteurist trappings, as its title indicates.) Aaron Hunter's Authoring Hal Ashby: The Myth of the New Hollywood Auteur (Bloomsbury, 2016) debunks the era's auteur-centred canon. And Peter Biskind's Star: The Life \& Wild Times of Warren Beatty (Simon \& Schuster, 2010) assigns authorial credit of Shampoo (1975) not to the film's nominal director, Hal Ashby, but to its leading star: 'If Shampoo had an auteur,' states Biskind, 'it was probably [Warren] Beatty rather than Ashby' (Biskind, p. 211). 
Chafing at the constraints of the canon, then, recent scholarship on the Hollywood Renaissance strives to discard the legacy of auteur theory. The Hollywood Renaissance seemingly dovetails with this endeavour, as Krämer and Tzioumakis indicate: 'It is ...important to challenge the overwhelming emphasis on directors in the literature on the Hollywood Renaissance and indeed in much of Film Studies as a whole' (p. xix). I can't mount a full-blown rebuttal here, but I remain unconvinced by the field's attacks on auteurism. All too often, it seems to me, the authors of these critiques fall back on the very auteurist assumptions they profess to discard. Still, one can only be happy that the fruits of their labour - The Hollywood Renaissance not least among them - cast a long overdue light on the era's forgotten, marginalized, and underappreciated players.

The Hollywood Renaissance does more than inflate flaccid reputations, however; it also launches compelling new perspectives on 'American cinema's most celebrated era' (as the book's playful sub-title describes it). Most studies of this cinema, as noted above, trace its genesis to 1967, with Bonnie and Clyde and The Graduate the pre-eminent catalysts. Justin Wyatt, however, seeks out other progenitors. As early as 1953, Wyatt reminds us, Otto Preminger's The Moon Is Blue tested the limits of screen permissibility. Flouting Hollywood's puritanical codes, Preminger's risqué depiction of sexuality suggested the potential for a Hollywood cinema governed by 'more adult subject matter' (p. 2). Further taboo-breaking movies, such as Splendor in the Grass (1961) and The Pawnbroker (1965), gradually emerged, galvanized by the European art cinema. Most significant, for Wyatt, is Mike Nichols' Who's Afraid of Virginia Woolf? (1966). Shrewdly combining prestige and marketability - the high-profile casting of Elizabeth Taylor and Richard Burton fulfilled both criteria - Nichols' film displayed the elements necessary to gain leniency from Hollywood censors, despite its ribald content. By pushing Hollywood toward adult themes, Who's Afraid of Virginia Woolf? prepared the way for Bonnie and Clyde, The Graduate, and a string of Xrated Renaissance 'landmarks' such as Midnight Cowboy (1969) and Last Tango in Paris (1972). For Wyatt, Nichols' melodrama provided nothing less than 'the catalyst for this fertile period of American film history' (p. 16). 
Other chapters contribute new knowledge to the canon. If Nicholas Godfrey (in The Limits of Auteurism) contests the reputed stylistic radicalism of Easy Rider, Yannis Tzioumakis argues that the film's production, too, was not only less anomalous but also less 'independent' than its mythology implies. Tzioumakis presents a robust case against the prevailing apocrypha. Invariably praised as a feat of independent production, Easy Rider (according to legend) depended on a major studio - Columbia Pictures - only tangentially, for the purposes of theatrical distribution. Columbia's stake in the film, however, most likely exceeded that of mere distributor. According to Tzioumakis, Columbia participated in Easy Rider from the outset, almost certainly as a financier, and to such a degree as to directly shape the film's audio-visual style and marketability. Easy Rider's 'saleable' collage score, for instance consisting of pre-existing rock songs performed by Jimi Hendrix, Steppenwolf, The Byrds, and others - required the deep coffers of a major studio, so costly were the songs' film rights. In sum, Tzioumakis demonstrates 'the utmost significance of Columbia in [Easy Rider's] success' (p. 122) and demystifies - indeed, deromanticizes - the film's fabled production history.

A profound influence on the Hollywood Renaissance, critics contend, was the European art cinema of the 1950s and 1960s. Just as seminal - though seldom recognized as such - was the American underground cinema of the 1960s, not least the subversive, countercultural films produced or directed by Andy Warhol. So argues Gary Needham in his trenchant analysis of John Schlesinger's Midnight Cowboy. Of all the Hollywood Renaissance movies, Needham claims, Midnight Cowboy bears its underground stripes most flagrantly. Jon Voight's male hustler - virile, ostensibly straight, turning tricks in cowboy get-up - recycles an archetype extensively mined in Warhol's corpus (e.g. My Hustler, 1965); Warhol 'superstars' (such as Viva and Ultra Violet) surface in cameo roles; a Warhol silkscreen adorns part of the mise-en-scène; underground stylistics (self-consciously primitive and amateurish) become fodder for pastiche; and one dramatic set-piece, in which Joe Buck (Voight) and Ratso Rizzo (Dustin Hoffman) attend an underground party, is strongly redolent of Warhol's Factory scene, replete with musical allusions to The Velvet Underground (pp. 134-137). 
Andy Warhol, indignant at Hollywood for encroaching on underground terrain and domesticating its subject matter, immediately ushered Flesh (1968) into production 'as a "this is how we do it in the underground" response to the territorial hijacking of the cinematic hustler' (p. 143). Directed by Paul Morrissey, Flesh set out to present 'a more explicit and "authentic" representation of hustling' as compared to Hollywood carpetbaggers like Midnight Cowboy (p. 130). By flaunting actor Joe Dallesandro's erect penis, for instance, Flesh exposed the limits if not of auteurism in toto, then certainly of auteurism within the Hollywood mainstream - this despite the much-vaunted 'new freedom of the screen' available in the American commercial cinema of the late-1960s. In all, Needham sheds fascinating light on a rival mode of production heretofore 'written out of the Hollywood Renaissance' (p. 132). (That the American underground permeated the Hollywood Renaissance is reaffirmed in Melis Behlil's adept chapter on Michelangelo Antonioni's Zabriskie Point [1970], p. 161.)

The Hollywood Renaissance's corps of contributors ensures a high overall quality. Each chapter, organized chronologically around a single film, delivers perspicacious analysis. Methodologies vary, but always to profitable effect. Most notable, perhaps, is the synthesis of empirical and theoretical analysis employed, separately, by Warren Buckland and R. Colin Tait. Buckland scrutinizes editing manuals and editors' memoirs, the better to elucidate not only the creative innovations of Dede Allen (and others), but also the collaborative interplay and divisions of labour between editors and directors. Tait, meanwhile, examines Robert De Niro's script annotations, the substance of which attests that the actor - in his 1970s collaborations with Scorsese - employed a holistic approach to screen performance. Not least, The Hollywood Renaissance (like Godfrey's monograph) represents a serious challenge to the primacy of the auteur theory, both viz-à-viz American cinema circa 1967-1975 and within the discipline at large. In this respect, both books strive to push film theory in fresh directions.

\section{Contemporary Chinese Cinema}

As Mainland China's film industry continues its precipitous rise, film theorists sharpen their gaze on China's transnational status. This topic is taken up, with contrasting emphases, by 
two recent monographs: Dorothy Lau's Chinese Stardom in Participatory Cyberculture and Gina Marchetti's Citing China, to be reviewed seriatim.

Lau's book explores the effects wrought by cyberspace on Chinese star discourse. How have web-based fora (such as Facebook and YouTube) 'democratized the star-making process' ( $\mathrm{p}$. 4)? How have transnational cinema's technological advances reconfigured global images of 'Chineseness'? In the digital-media age, Lau argues, star personae coalesce 'democratically' through bottom-up (e.g. fan-authored) and top-down (e.g. studio-driven) practices. Today, fan consumers seldom only consume: by creating and circulating digital artefacts (blogs, videos, podcasts, and the like), fans become 'full participants in cultural production,' intervening 'unofficially' in the discursive aspects of stardom (p. 4). Such arguments are apt to make seminal theories of film stardom (e.g. Richard Dyer's Stars [BFI: 1979]) look passé, if not downright antiquated. But Lau insists that digital modes of star discourse, while new, constitute less a radical departure from traditional fan practices (e.g. fanzines; fan clubs) than a virtual outgrowth and manifestation of those démodé activities. All the same, the web-based star system 'generates new ways of understanding, discussing, and consuming fame' (p. 3).

What is the status of Chineseness in this context? Lau mounts a theory of 'the cine-cyber imaginary,' the crux of which construes Chineseness as a hybrid, web-based phenomenon indissolubly linked to the (Chinese) star's cinematic identity. Chineseness thus meshes the star's screen persona, extratextual star discourse (including, typically, an authorized online presence), and unofficial virtual artefacts generated by fans. Subject to many stakeholders, the Chinese star image exists in constant flux. Lau exemplifies this thesis through chapterlength analyses of individual stars (Donnie Yen, Jackie Chan, Jet Li, Zhang Ziyi, Takeshi Kaneshiro), each coupled with a distinct cyber-platform (e.g. Flickr) and a new-fangled fan activity (e.g. photo sharing).

As Lau's analyses demonstrate, global cyberculture and transnational filmmaking converge to destabilize or dissipate Chinese nationalism. In cyberspace, as in global cinema, Chineseness dematerializes into virtual ambiguity. A central topos here is the star body, frequently read as a symbol of national identity. When tourists upload 'selfies' taken at Jackie 
Chan's 'star' on the Hollywood Walk of Fame - and when, in these photos, they selfconsciously mimic Chan's iconic kung-fu pose - Chan's own body, with all its nationalistic connotations, is conspicuous by its absence. In its place resides mere digital pastiche. Here, then, a fan activity (photo sharing), circulated via an online platform (Flickr), 'empties out' the nationalism signified by Chan's star body, and effects 'an appearance without substance of Chinese nationalism' (p. 166).

Just as cyberculture evinces 'the new void of Chineseness' (p. 54), so transnational cinema begets the 'virtualization' of the Chinese star persona (p. 168). Lau offers as an instance Donnie Yen's martial-arts image. The star's Chineseness, on screen at least, hinges on the authenticity of his body in extremis. In Hong Kong films such as Ip Man (2008), Yen executes Chinese martial-arts techniques with (at least ostensible) corporeal authenticity. His recent transnational excursions, however, expunge the corpus from corporeality. By embellishing or displacing Yen's authentic martial-arts performance with 'CGI [computergenerated imagery] spectacles of the martial-arts body' (p. 52), movies such as Rogue One (2016) and The Monkey King (2014) virtualize and 'vex' Yen's embodiment of Chineseness. In all, Lau mounts a potent case for the diffusion of Chinese stardom in the internet age.

Some of Lau's factual assertions will need correction. Enter the Dragon (1973) is a film, not a television series (p. 7); Jackie Chan is in his mid-sixties, not his mid-fifties (p. 58); and Keanu Reeves' fame predated Speed (1994), not vice versa (p.141). Wu Xia (2011) and The One-Armed Swordsman (1967) are ascribed incorrect release dates (p. 53). Several unfortunate typos (Brat Pitt; Rouge One) recur throughout. And some frankly perplexing prose blights the book's first two chapters, to wit: '...this monograph situates the scrutiny in cyberculture and attempts to interrogate the meaning of conception within the context' (p. 19). These flaws notwithstanding, Lau's book valuably contributes to a growing body of literature nudging film theory beyond the filmic. (Plantinga's Screen Stories, by admitting all forms of screen media, does likewise.) This, then, is film theory for the twenty-first century: it acknowledges (and hypothesizes about) the impact of web-culture on all aspects of cinema, from the manufacture of star personae to new viral forms of film distribution and promotion. As a theory of Chinese film, moreover, it looks beyond China to Western and pan-Asian screen industries, with which post-Mao Chinese cinema is ever more tightly imbricated. 
Indeed, world film culture bears witness to a long-standing 'conversation' between Chinese and Western cinemas. As Gina Marchetti notes in Citing China, Sino-Western exchange is manifested cinematically through a conscious, purposive, and sometimes palimpsestic form of intertextuality. This cross-cultural dialogue, moreover, can be cyclical: global auteurs (e.g. Jean-Luc Godard; Martin Scorsese) fasten on Chinese aesthetics and subject matter; their films, shaped by Chinese culture and politics, reciprocally inform those of Chinese filmmakers (e.g. Chen Kaige; Jia Zhangke); and 'completing the cycle, filmmakers outside of China reenter the mix and exploit themes and techniques developed in Chinese-language cinema' (p. 8). So much intertextuality finds one impetus, of course, in economic necessity: by citing globally recognizable movies, filmmakers smooth the path to foreign funding and overseas distribution (p. 184). But there is another impetus too. The China-West 'conversation' represents, in not a few cases, an effort to forge 'common ground' between China and the rest of the world. Of what does this common ground consist? For Marchetti and for the filmmakers discussed in Citing China - Sino-Western dialogue, at its most elevated, strives for a cinematic solidarity rooted in 'progressive' politics: that is, anticapitalism, anti-imperialism, feminism, and pro-LGBTQ concerns (pp. 20-1).

By valorising films underpinned by Marxist doctrine, Citing China betrays the legacy of 1970s left-wing film theory. The book also superficially recalls, in its dazzling breadth of reference, Lesley Stern's The Scorsese Connection (BFI: 1995). Yet Marchetti's investigation is wholly original. Stern's book centres on a single oeuvre, but Marchetti's ambit is far wider, canvassing figures from Bernardo Bertolucci and Alfred Hitchcock to Ann Hui and Jet Li. The filmmakers she examines share 'a political urge to engage with China' (p. 184), doing so, in part, by 'citing' China. Such practices are de rigeur in postmodernism, the routines of which - bricolage, pastiche, quotation, allusion, and so on - liberate contemporary filmmakers from the 'anxiety of influence' and fears of derivativeness (p. 5). With surgical dexterity, Marchetti unpicks the citations embedded in particular films, not merely to trace their (sometimes surprising) lineage but also to show how filmmakers repurpose these intertexts to distinct political ends. 
In The Terrorizers (1986), for instance, Edward Yang purposefully evokes Michelangelo Antonioni's Blow-Up (1966), obliquely linking Antonioni's critique of the bourgeois West to Yang's own study of Taiwan society under martial law. In The World (2004), Jia Zhangke draws on the 1920s Soviet montagists - Sergei Eisenstein, Vsevolod Pudovkin, Dziga Vertov - to contrive a Marxist denunciation of migrant labour exploitation in Mainland China. Two modes of European realism (Italian neorealism and 'Bressonian' transcendental style) underpin allusions to China's self-image in Jia's Xiao Wu (1997) and Patrick Tam's After This Our Exile (2006). Ann Hui's Ordinary Heroes (1999) and Evans Chan's The Life and Times of Wu Zhongxian (2003) critique Hong Kong politics by way of Bertolt Brecht. In What Time Is It There? (2001), Tsai Ming-liang engages with Godard's La Chinoise (1967) in part through the casting of actor Jean-Pierre Léaud; Tsai's citation of Godard and Léaud ('mummified' by Tsai as an icon of the nouvelle vague) 'reimagines the encounter between China and France in the post-Mao/post-May 1968 era' (p. 129). In Clara Law's Like a Dream (2009) - a skewering of 'the patriarchy' and its baleful effects on Chinese women Hitchcock's Vertigo (1958) affords the prime reference point.

Citing China is a model of textual and ideological exegesis. Marchetti brilliantly untangles elaborate webs of intertextuality, laying bare the radical potentiality of each film's citations. If Marchetti seems tacitly sympathetic to (what Plantinga calls) estrangement theory - she doesn't, after all, disavow the purported 'deadening impact' of mainstream cinema (p. 20), while 'aesthetic avant-gardism' is touted as the surest route to political awakening and activism - her chapter on Bruce Lee's The Way of the Dragon (1972) and Louis Leterrier's Unleashed (aka Danny the Dog, 2005) belies the premise that popular cinema, perforce, nullifies aesthetic innovation and political expression. This chapter, in fact, delivers one of Marchetti's most inspired linkages: the Colosseum locale in The Way of the Dragon finds a counterpart in Unleashed's bone-dry swimming pool, both milieus conjoined by notions of class hierarchy and Western imperialism (pp. 146-7). I suspect that this adroit nexus can be credited to Marchetti herself, rather than to Unleashed's director (Leterrier) or writer (Luc Besson).

This brings me to a slight equivocation. As with the 'connection' between Unleashed and The Way of the Dragon, it is not always clear that Marchetti's 'webs of citations' derive 
consciously from the filmmakers. Marchetti states that such citations are 'very conscious' artistic practices (p. 18), but, at times, one has occasion to doubt this assertion - especially when the ascribed citations become overly abundant. Consider Jia Zhangke's The World. According to Marchetti, Jia's film 'self-consciously' quotes Jean-Luc Godard, Gus Van Sant, and Lars von Trier (p. 29); alludes to Soviet montage, Italian neorealism, and epic theatre (p. 51); pays homage to Martin Scorsese (p. 31); assimilates Bollywood (p. 33); resembles Japanese anime (p. 29); evokes Yasujiro Ozu's pictorial style (p. 29); 'echoes’ Andrei Tarkovsky's Andrei Rublev (1969) (p. 36); and cites films by Fruit Chan, Wang Xiaoshuai, and Feng Xiaogang (p. 43-44). Did Jia truly conceive this blizzard of citations? Or have (at least some of) these intertexts been mapped onto The World retrospectively by an ingenious, cinephilic film analyst?

In the final analysis, I doubt it matters whether every 'citation' can be shown to be consciously intended by the filmmaker. The films examined by Marchetti, whatever their debt to world cinema, now exist as their own entities: they circulate on world screens, ready to be cited by other filmmakers, just as they themselves cited or otherwise evoked a rich heritage of intertextual filmmaking from across the China-West divide. Marchetti's fascinating book deserves to be circulated just as widely.

\section{Books Reviewed}

Godfrey, Nicholas, The Limits of Auteurism: Case Studies in the Critically Constructed New Hollywood (New Jersey and London: Rutgers University Press, 2018). ISBN: 978081358 9145.

Kiss, Miklós and Willemsen, Steven, Impossible Puzzle Films: A Cognitive Approach to Contemporary Complex Cinema (Edinburgh: Edinburgh University Press, 2018). 14744 31976.

Krämer, Peter and Tzioumakis, Yannis, eds., The Hollywood Renaissance: Revisiting American Cinema's Most Celebrated Era (New York and London: Bloomsbury Academic, 2018). ISBN: 1501337882. 
Lau, Dorothy Wai Sim, Chinese Stardom in Participatory Cyberculture (Edinburgh:

Edinburgh University Press, 2018). ISBN: 9781474430333.

Marchetti, Gina, Citing China: Politics, Postmodernism, and World Cinema (Honolulu: University of Hawaii Press, 2018). ISBN: 978080824866570.

Plantinga, Carl, Screen Stories: Emotion and the Ethics of Engagement (Oxford: Oxford University Press, 2018). ISBN: 9780190867140. 